\title{
KAJIAN ETIK PENELITIAN DALAM BIDANG KESEHATAN DENGAN MELIBATKAN MANUSIA SEBAGAI SUBYEK
}

\author{
Luh Titi Handayani \\ Fakultas Ilmu Kesehatan Universitas Muhammadiyah Jember \\ Email :luhtiti@unmuhjember.ac.id
}

\begin{abstract}
Abstrak
Artikel ini mendiskusikan tentang kajian etik penelitian dalam bidang kesehatan dengan melibatkan manusia sebagai subyek pada studi literatur dan studi terhadap kasus nyata yang terjadi. Metode analisa yang digunakan dengan menggunakan studi literature, artikel terhadap kasus ditinjau dari aspek dilema etik penelitian keseharian. Prinsip dasar etika dan hukum dalam profesi kesehatan dengan adanya hubungan kontraktual-profesional antara peneliti dan subyek. Permasalahan etik dalam penelitian antara lain fabrication, falsification, plagiarism, exploitation, injustice, duplication. Kegiatan dalam proses penelitian harus perpedoman pada integritas, jujur dan adil. Prinsip-prinsip etika dan hukum terutama dalam hubungan peneliti dan subyek penelitian dalam bidang kesehatan harus selalu dijunjung tinggi berdasarkan prinsip etik penelitian kesehatan.
\end{abstract}

\begin{abstract}
This article discusses the study of research ethics in the field of health by involving humans as subjects in literature studies and studies of real cases that occur. The method of analysis used by using literature studies, articles on cases in terms of aspects of the ethical dilemma of daily research. The basic principles of ethics and law in the health profession with the existence of contractualprofessional relations between researchers and subjects. Ethical problems in research include fabrication, falsification, plagiarism, exploitation, injustice, duplication. Activities in the research process must be guided by integrity, honesty and fairness. Ethical and legal principles, especially in the relationship of researchers and research subjects in the health sector must always be upheld based on the principles of health research ethics.
\end{abstract}




\section{PENDAHULUAN}

Tujuan penelitian adalah untuk mengembangkan keilmuan dengan berupa fakta yang baru dan menjadi dasar untuk pemecahan masalah. Ilmu dan penelitian tidak dapat dipisahkan. Ilmu berkembang dengan penelitian dan penelitian tidak akan terpecahkan tanpa ilmu. Ilmu merupakan filosofi sedangkan penelitian adalah tindakan dalam membangun kerangka ilmu pengetahuan. Metode ilmiah merupakan suatu tahapan dari penelitian dalam pengembangan suatu ilmu (Sastroasmoro, 2011).

Peneliti dalam melakukan penelitian tidak akan berhasil tanpa bantuan orang lain. Diperlukan responden yang akan menyisihkan waktunya untuk terlibat dalam penelitian, disini diperlukan timbal balik peneliti kepada responden. Respon dari responden yang secara sukarela memberikan informasi penelitian perlu dihargai atas informasi, kesediaan dan kejujurannya dan hal inilah yang disebut kode etik penelitian (Kemenkes, 2017).

Penelitian bidang kesehatan mempunyai tujuan untuk mendapatkan informasi dan data dalam mengembangkan serangkaian kegiatan ilmiah. Ranah penelitian bidang kesehatan mempunyai perbedaan karakteristik, namun saling berkaitan serta dalam satu rangkaian kerangka keilmuan bidang kesehatan (Sastroasmoro, 2011).

Penelitian bidang kesehatan dapat dilakukan baik kegiatan klinis atau sosial akan melibakan manusia sebagai subjek. Manusia yang terlibat sebagai subyek penelitian memiliki yang dimiliki sejak dilahirkan. Hak ini tidak dapat dikurangi atau dilanggar. Hal tersebut disebut dengan hak asasi. Seorang subyek dengan melibatkan manusia dalam proses penelitian kemungkinan akan mengalami ketidaknyamanan bahkan akan mendapatkan risiko dari dampak penelitian. Kesediaan dan martabat subyek tersebut harus dihargai. Kewajiban tersebut disebut dengan etik penelitian kesehatan (Kemenkes, 2017). Penelitian dimana melibatkan manusia sebagai subyek diterima secara etik apabila menggunakan metode ilmiah yang baik dan benar (Setywan, 2013).

Etik merupakan suatu filosofi yang mendasari suatu prinsip. Kegiatan peneitian akan berjalan baik dan benar (the right conduct) apabila menerapkan prinsipi-prinsip etika penelitian yang harus dipatuhi. Aturan dan etik tersebut harus dipahami seseorang yang akan melakukan penelitian. Aspek etik dalam penelitian terkait dengan sifat jujur, utuh dan bertanggungjawab terhadap subyek penelitian, memperhatikan aspek rahasia, anonimity dan sopan (Setywan, 2013).

Etika penelitian memerlukan pedoman etis dan norma yang mengikuti perubahan dinamis masyarakat. Sikap ilmiah (scientific attitude) perlu dipegang teguh oleh seorang peneliti berdasarkan prinsip etik dan norma penelitian demi menjamin subyek dihormati terhadap privasi, kerahasiaan, keadilan dan mendapat manfaat dari dampak penelitian dengan menerapkan prinsip adil, benar dan humanistik (Kemenkes, 2017).

\section{TINJAUAN PUSTAKA}

Peneliti adalah seseorang yang mempunyai keilmuan sesuai 
bidangnya dan tugas seorang peneliti adalah membuktikan asumsi dan hipotesis melalui penelitian ilmiah. (LIPI, 2013).

Pembenaran terhadap etis atau laik etik dalam penelitian imiah dalam melibatkan manusia sebagai subyek dengan mempertimbangkan beberapa nilai ilmiah dan nilai sosial dalam menghasilkan pengetahuan dan diperlukan sarana untuk melindung dan memberikan serta meningkatkan kesejahteraan bidang kesehatan (Kemenkes, 2017).

Kegiatan penilitian dilakukan berdasarkan prinsip dan kaidah serta metode ilmiah yang disusun secara sistematis dalam upaya mendapatkan data yang dibutuhkan dalam penelitian, memberikan pemahaman dan membuktikan asumsi dan hipotesis penelitian dalam rangka merumuskan kesimpulan penelitian dan mengembangkan ilmu pengetahuan dan teknologi (LIPI, 2013).

Upaya untuk menjaga kehormatan profesi dari peneliti dan dalam meningkatkan mutu penelitian serta kredibilitas lembaga diperlukan penegakan terhadap etika penelitan. Hal ini penting untuk menerapkan prinsip etik, kejujuran dan keadilan peneliti yang bermanfaat meningkatkan kesadaran peneliti, mengirangi resiko etik seperti pelanggaran etik dan memberikan nilai pembelajaran bagi peneliti sendiri (LIPI, 2013).

\section{Manfaat}

Penelitian dengan menerapkan prinsip etik akan memberikan nilai positif atau bagian yang menguntungkan dari suatu penelitian. Nilai positif atau keuntungan ini dapat berlaku untuk individual subjek serta melindungi subyek dari dampak pelangaran etik.

\section{Prinsip Etik}

Prinsip etik penelitian di bidang kesehatan yang mempunyai secara etik dan hukum secara universal mempunyai tiga prinsip, yaitu (Kemenkes, 2017):

1. Menghormati harkat martabat manusia (respect for persons).

Bentuk penghormatan terhadap harkat martabat manusia sebagai pribadi (personal) yang memiliki kebebasan berkehendak atau memilih dan sekaligus bertanggung jawab secara pribadi terhadap keputusannya sendiri. Prinsip ini bertujuan untuk menghormati otonomi, yang mempersyaratkan bahwa manusia yang mampu memahami pilihan pribadinya untuk mengambil keputusan mandiri (self-determination), dan melindungi manusia yang otonominya terganggu atau kurang, mempersyaratkan bahwa manusia yang berketergantungan (dependent) atau rentan (vulnerable) perlu diberikan perlindungan terhadap kerugian atau penyalahgunaan (harm and abuse).

2. Berbuat baik (beneficence) dan tidak merugikan (nonmaleficence)

Prinsip etik berbuat baik menyangkut kewajiban membantu orang lain dilakukan dengan mengupayakan manfaat maksimal dengan kerugian minimal. Subjek manusia diikutsertakan dalam penelitian kesehatan dimaksudkan membantu tercapainya tujuan penelitian kesehatan yang sesuai 
untuk diaplikasikan kepada manusia.

Prinsip etik berbuat baik, mempersyaratkan bahwa: 1) Risiko penelitian harus wajar (reasonable) dibanding manfaat yang diharapkan, 2) Desain penelitian harus memenuhi persyaratan ilmiah (scientifically sound), 3) Para peneliti mampu melaksanakan penelitian dan sekaligus mampu menjaga kesejahteraan subjek penelitian, 4) Prinsip do no harm (non maleficent - tidak merugikan) yang menentang segala tindakan dengan sengaja merugikan subjek penelitian.

Prinsip tidak merugikan adalah jika tidak dapat melakukan hal yang bermanfaat, maka sebaiknya jangan merugikan orang lain. Prinsip tidak merugikan bertujuan agar subjek penelitian tidak diperlakukan sebagai sarana dan memberikan perlindungan terhadap tindakan penyalahgunaan.

3. Keadilan (justice)

Prinsip etik keadilan mengacu pada kewajiban etik untuk memperlakukan setiap orang (sebagai pribadi otonom) sama dengan moral yang benar dan layak dalam memperoleh haknya. Prinsip etik keadilan terutama menyangkut keadilan yang merata (distributive justice) yang mempersyaratkan pembagian seimbang (equitable), dalam hal beban dan manfaat yang diperoleh subjek dari keikutsertaan dalam penelitian. Ini dilakukan dengan memperhatikan distribusi usia dan gender, status ekonomi, budaya dan pertimbangan etnik. Perbedaan dalam distribusi beban dan manfaat hanya dapat dibenarkan jika didasarkan pada perbedaan yang relevan secara moral antara orang-orang yang diikutsertakan. Salah satu perbedaan perlakuan tersebut adalah kerentanan (vulnerability). Kerentanan adalah ketidakmampuan untuk melindungi kepentingan diri sendiri dan kesulitan memberi persetujuan, kurangnya kemampuan menentukan pilihan untuk memperoleh pelayanan atau keperluan lain yang mahal, atau karena tergolong yang muda atau berkedudukan rendah pada hirarki kelompoknya. Untuk itu, diperlukan ketentuan khusus untuk melindungi hak dan kesejahteraan subjek yang rentan.

\section{PEMBAHASAN}

\section{Prinsip Etik}

Prinsip-prinsip Etika menurut (Suryadi, 2009) adalah etika yang berfungsi sebagai dasar yang bersifat kritis yang bersumber pada empat kaidah dasar. Bersama dengan teori etik dan sistematika yang berdasar nilai dan landasan etik profesi yaitu otonomi, benefience, non maleficience, justice.

Prinsip Bioetik Islam didasarkan pada prinsip persamaan (selain takwa), persaudaraan manusia (dalam tauhid), kebebasan untuk memilih tanpa ada paksaan (prinsip selektifitas dan kreativitas) sehingga adanya pilihan membatasi kebebasan, tujuan akhir dan cara harus konsisten untuk kebenaran, kebaikan hanya dari Allah dan keadilan antara hak dengan kewajiban yang menghargai kontribusi dan usaha atau pilihan 
individu. Bioetik Islam merupakan perpaduan antara hak dan kewajiban, kebebasan dan tanggung jawab, penalaran (logika) dan hati nurani (Suryadi, 2009).

\section{Pelanggaran Etik}

Serorang peneliti dalam melaksanakan penelitian haris memperhatikan etika penelitian antara lain (Setywan, 2013): 1) Plagiarisme yaitu mengutip ide atau tulisan orang lain tanpa menuliskan sumber dalam pustaka, 2) melakukan manipulasi penelitian yaitu mengarang dan membuat data sendiri tanpa melakukan tahapan pengambilan data, 3) tidak menyebutkan identitas penelitia dan objek serta tempat penelitian, 4) independensi penelitian.

Masalah-masalah yang berkaitan dengan etika terdapat beberapa masalah etika dalam penelitian seperti misalnya: 1)Tidak Adanya Informed consent, 2) Pemaksaan atau intimidasi terhadap relawan, 3) Menggunakan populasi yang rentan, 4) Eksploitasi populasi rentan, 5) Tidak memberikan informasi, 6) Tidak memberikan pengobatan, 7) Tidak memberikan informasi mengenai risiko, 8) Memnbahayakan subyek, 9) Risiko bagi subyek melebihi manfaat, 10) Penipuan, 11) Pelanggaran hak-hak subyek (KNEPK, 2011).

\section{Aplikasi Prinsip Etik dalam Penelitian Kesehatan}

Pelaksana penelitian mempunyai kewajiban menjamin penelitian klinik yang akuntabel dan transparan serta melindungi subyek dan meningkatkan aspek manfaat harus memperhatikan hal sebagai berikut: a. melaksanakan Penelitian
Klinik sesuai persetujuan Etik (ethical approval), b. melakukan jaga mutu penelitian klinik; c. Menyediakan atau memfasilitasi penyelenggaraan sistem evaluasi mutu eksternal (External Quality Assessment System); dan d. melakukan pembaharuan status tahapan pelaksanaan Penelitian Klinik dan perkembangan informasi terkait perubahan Set Data (Peraturan Menteri no 66, 2013)

\section{Etik Penelitian Kesehatan Dalam Lingkup Budaya Indonesia} (KNEPK, 2011).

Indonesia adalah suatu negara kepulauan yang yang terbesar di dunia. Kebanyakan dari kepulauan ini terletak di bagian selatan dari katulistiwa. Akibat pemisahan oleh laut tiap pulau cenderung mengembangkan ciri-ciri sosial, kebudayaan, dan ekonomi tersendiri, dan kelompok - kelompok kecil dimungkinkan mempertahankan identitas budaya dan bahasanya. Berbagai kelompok kebudayaan di masyarakat Indonesia adalah suatu keadaan dan perkembangan alami sebagai akibat keadaan geografisnya. Masyarakat yang sangat beranekaragam dari segi kelompok budayanya ini seringkali menambah permasalahan komunikasi, terutama pada saat dibuat Persetujuan Setelah Penjelasan (PSP) atau Informed ConsentHal yang diperhatikan bahwa prinsip dasar pertama dalam etika penelitian, respect for persons, atau otonomi perorangan, tidak selalu dapat diterapkakan di masyarakat Indonesia. Di kebanyakan komunitas di Indonesia, lebih berlaku pendekatan kolektif, di mana seorang subyek penelitian atau seorang 
pasien, terutama yang perempuan, tidak merasa mampu untuk mengambil keputusan seorang diri, tapi sering menyerahkan pengambilan keputusan (atau sedikitnya mengikutsertakan) itu kepada suami, ayah, atau kepala komunitas.

Implikasi dari keadaan ini adalah, bahwa pelaksanaan etika penelitian kesehatan, harus dicegah penyeragaman, dan diutamakan pertimbangan keanekaragaman. Artinya, dalam melakukan penelitian dengan subyek manusia, penerapan etika perlu disesuaikan dengan keadaan setempat, terutama soal bahasa, nilai-nilai, normanorma, adat-istiadat, kebiasaan, yang berlaku. Pada dasarnya, pendekatannya adalah paham pluralis atau multikulturalisme, yang esensinya adalah menghargai dan menghormati perbedaan. Oleh karena itu, peneliti dan sponsor penelitian, baik dari dalam maupun dari luar Indonesia harus memahami keberagaman tersebut dan menyadari serta peka bahwa: 1. Prinsip etika ketiga yaitu keadilan (justice) merupakan pertimbangan utama di atas prinsip pertama (autonomy) dan prinsip ke dua (beneficence). 2. Budaya Indonesia lebih mengutamakan kebersamaan, gotong royong, dan kesejahteraan keluarga dan masyarakat 3. Di Indonesia, sebagian besar masyarakatnya adalah kelompok masyarakat yang belum beruntung, terbelakang dan miskin, sehingga tergolong sebagai kelompok rentan (vulnerable group) 4. Peneliti dan sponsor perlu mempelajari dan memahami budaya, keyakinan, kepercayaan, kebiasaan masyarakat di tempat penelitian dilakukan

\section{Isu yang Berkenaan dengan Prinsip Etis (Kemenkes, 2017)}

definisi diartikan sebagai keuntungan, dari sesuatu layanan jasa yang semula tidak ada dan masyarakat sebgai penerima keuntungan hal ini seorang peneliti sudah menerapkan prinsip etik.

Privasi seorang subyek penelitian dalam konteks penelitian merupak hal penting dan krusial yang harus diperhatikan. Serorang peneliti tidak boleh memaksakan kehendak pada subyek. Peneliti harus memperhatikan hak-hak subyek. Bila sekiranya sebyek menolak sebagau responden seorang peneliti harus menghormati keputusan tersebut. Perbedaan latar belakang pengetahuan, budaya, keuntungan dan resko menjadi dasar pertimbangan keputusan subyek. Kadangkala seorang peneliti harus melibatkan pihak lain untuk mendapatkan data yang diperlukan yang sekiranya data tersebut memang harus didapatkan untuk menguji asumsi dan hipotesis.

Penelitian bidang kesehatan seringkali didapat keterkaitan antar subyek atau antar bidang kesehatan lain atau intas sektoral untuk mendapatkan data yang secara kualitas dan kuantitas yang baik. Seringkali hal ini yang mendapatkan kendala dalam proses penelitian. Jejaring dalam penelitian kesehatan tampak pada gambar di bawah ini. 


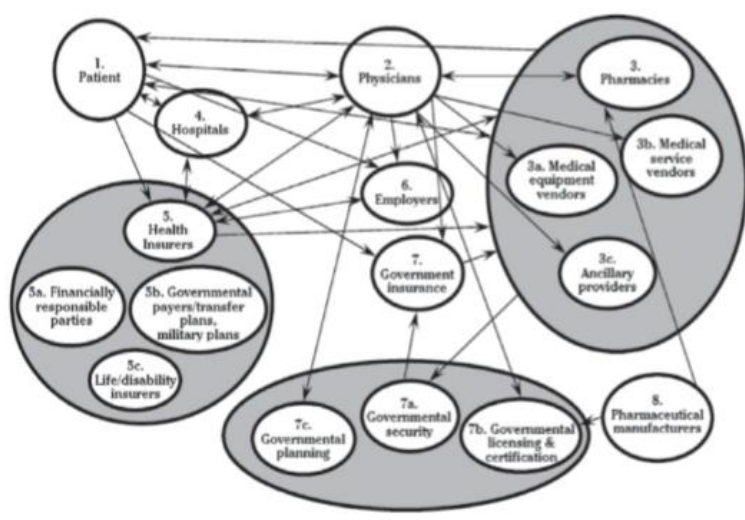

Gambar 1. Jejaring hubungan dalam Sistem Kesehatan

\section{Tanggung Jawab dan Tugas Komisi Etik Penelitian Kesehatan (KNEPK, 2011).}

Setiap institusi bidang kesehatan yang menyelenggarakan kegiatan penelitian baik dalam tata kelola di bidang pendidikan dan rumah sakit diharapkan mempunyai komite etik penelitian kesehatan dimana salah satu fungsi penting dari komisi ini adalah melindung subyek dan penelitian dari jeratan hukum dan tanggung jawab peneliti. Pembahasan penelitian dibidang kesehatan dimana manusia sebagai subyek penelitian adalah tugas dari komisi etik dalam dalam memantau kegiatan penelitian mulai proses dampai dengan publikasi.

Protokol yang masuk selanjutnya diterima oleh sekretariat dan dilanjurkan membuat resume untuk selanjutnya didistribusi kepada penelaah. Komisi etik bekerja sesuai dengan waktu yang telah ditentukan. Komisi etik melakukan pertemuan dengan tim minimal sekali sebulan untuk membahas usulan ethical clearance. Telaah etik dilakukan oleh $2-3$ orang. Hasil telaah didapatkan beberapa keputusan apakah dilanjutkan atau full board yang artinya peneliti melakukan presentasi untuk diklarifikasi. Persetujuan ethical clearance diambil berdasarkan suara terbanyak dari anggota yang hadir dalam rapat tersebut. Rapat dianggap sah jika dihadiri minimal setengah jumlah anggota ditambah 1 orang dan berjumlah ganjil.

Info terkini bahwa KEPKN melakukan registrasi terintegrasi melalui era digital dari komisi etik seluruh Indonesia. Sistem ini akan memamantau pelaksanaan proses ethical clearence. Sistem digital harus dikuasi oleh peneliti, sekretaris, sekretariat, penelaah dan ketua etik sebagai media komunikasi secara cepat dan terintegrasi untuk memutuska kelaikan etik dari protokol ethical cleareance.

Penelitian dipantau oleh komisi etik dan akan diambil keputusan jika disaat proses penelitian didapatkan kasus yang mengandung resiko baik pada peneliti dan subyek. Ketua Komisi Etik bertanggung jawab atas jalannya rapat pertemuan komisi. Hasil dan keputusan rapat dicatat dan didikumentasi oleh sekretaris untuk kemudian disampaikan kembali dengan ketua etik untuk dikekuarkan sertifikat ethical clearence. Sekretaris tersebut juga menerima laporan penelitian selama penelitian sedang berjalan sampai penelitian selesai.

\section{SIMPULAN}

Etik bidang kesehatan dengan melibatkan manusia sebagai subyek tidak terlepas dari penalaran, pembenaran dan konflik moral diri pribadi. Keputusan etik berhubungan dengan hukum yang berkaitan dengan konflik baik bersifat personal atau kelompok. Norma etika pada saat ini banyak yang tumpang tindih 
dengan / atau setidaknya dipengaruhi oleh norma hukum dan yang melatarbelakanginya (finansial, budaya, sosial).

Perilaku manusia dan hubungan antar manusia diatur oleh hukum dan aturan lain yang baku. Kaidah dan moral diatur oleh hukum dan etik untuk mendapatkan hasil yang lebih baik. Selanjutnya bahwa pertimbangan etik penelitian dengan melibatkan manusia sebagai subyek sangat diperlukan perlindungan baik dari sisi peneliti ataupun subyek. Hendaknya peneliti menerapkan metode ilmiah yang baik dalam pendekatan penelitian.

Pola pikir didasarkan pada hukum akan membawa pada aturan. Etik mendalami masalah dengan tidak hanya melihat hal yang material (terlihat, terobservasi, terukur, dll) tetapi juga nilai hal yang melatarbelakangi. Penerapan prinsipprinsip etika dan hukum harus selalu dijunjung tinggi oleh setiap peneliti, karena akan menyelamatkan peneliti dari gugatan dan tuntutan juga sekaligus merefleksikan pribadi sebagai profesi yang luhur dan mulia sepanjang masa.

\section{DAFTAR PUSTAKA}

Utarini A, Probandari A, Lestari T, dan Hartriyanti Y. Handout Kuliah Metode Penelitian: Etika Penelitian Kesehatan Masyarakat. Yogyakarta: Fakultas Kedokteran UGM; 2010.

Kemenkes, R. (2017). Pedoman dan Standar Etik Penelitian dan Pengembangan Kesehatan nasional. Jakarta.
KNEPK, K. K. (2011). Pedoman Etik Penelitian Kesehatan. Jakarta: Tidak di Publikasi.

Oetarjo, D., \& Sachrowadi, Q. (2013). Isu Etik dalam Penelitian di Bidang Kesehatan. Jakarta: Universitas Yarsi.

Peraturan Menteri no 66, R. I. (2013). Penyelenggaraan Registri Penelitian Klinik. Jakarta: Kemenkes.

Sastroasmoro, S. (2011). Dasar dasar Metodologi Penelitian Edisi ke 4. Sagung Seto: Jakarta.

Setywan, D. A. (2013). Etika dan Kode Etik Penelitian. Surakarta: Tidak Di publikasi.

Suryadi, T. (2009). Prinsip-Prinsip Etika dan Hukum Bidang Kedokteran. Medan: Tidak di Publikasi.

Wella, Y. (2008). Etika Penelitian Kesehatan. Riau: Universitas Pekanbaru. 